\title{
Firm Performance and Corporate Social Environmental Initiatives in the Wake of a Health Pandemic
}

\author{
Osereme Omoike ${ }^{1}$, Uwalomwa Uwuigbe ${ }^{1}$, Philip Alege ${ }^{2}$, Bukola Uwuigbe ${ }^{1}$, Osazuwa Peter Nosakhare ${ }^{3}$ \& Osariemen \\ Asiriuwa $^{1}$ \\ ${ }^{1}$ Department of Accounting, Covenant University, Nigeria \\ ${ }^{2}$ Department of Economics, Covenant University, Nigeria \\ ${ }^{3}$ Department of Accounting, University of Benin, Nigeria \\ Correspondence: Osereme Omoike, Department of Accounting, Covenant University, Nigeria.
}

Received: April 23, 2020

Accepted: May 30, 2020

Online Published: November 30, 2020

doi:10.5430/ijfr.v11n6p211

URL: https://doi.org/10.5430/ijfr.v11n6p211

\begin{abstract}
The study re-examines the relationship between firm share price performance and Corporate Social Environmental Reporting (CSER) initiatives in the wake of a global health pandemic. A comparative analysis was done between the contributions made by listed and non-listed firms in Nigeria towards the pandemic. A comparative analysis of the share price (SP) of listed companies was carried out before the announcement of the pandemic, after the announcement of the pandemic and COVID -19 contributions. A panel regression analysis was conducted. It involved a sample of 70 listed firms in the Nigerian Stock Exchange over a five-year period (2013-2017). The comparative analysis of contributions revealed that listed firms though fewer in number made significantly more contributions than unlisted firms. The study found significant drop in SP after the announcement of a pandemic by the World Health Organisation (WHO). The study also found that SP performance and firm size has a positive and significant relationship with CSER initiatives. The analysis of contributors from listed and non- listed firms in Nigeria towards COVID-19 reveal that only corporate organizations with adequate resource slack can make significant contributions to curtail the spread of the epidemic. The study recommends that corporate organizations should pursue financial capacity in other to make significant CSER investments and expect a change in societal demands and stakeholder expectations in the no distant future.
\end{abstract}

Keywords: Covid-19, pandemic, share price, slack resources, World Health Organization

\section{Introduction}

The events of the last few months wherein the world witnessed an unprecedented outbreak of a major health pandemic (COVID-19) reveals that CSER is of a major concern. Its relevance extends beyond national boundaries. The globalised nature of businesses by major corporations also calls for a concerted or joint effort beyond geographical boundaries. Thus, environmental and social investments are no longer restricted to geographical areas. This is especially true given that some multi-national corporations have subsidiaries in other countries. Therefore, environmental health hazards or pandemic in regions where subsidiaries of multinational corporations exist, could adversely affect the bottom line of the entire entity. The recent pandemic also raises questions on the type of environmental impact assessment been conducted by businesses.

Organisational resources in Nigeria have thinned out due to the sharp decline in oil price revenue. Thus affecting the Nigeria government spending power. Furthermore, the health pandemic led to the shutting down of several business activities and disruption of supply chains. Developing countries like Nigeria which are highly import dependent witnessed sharp decline in revenue generation. The increasing resource scarcity makes firms much more strategic in their investment towards CSER or other philanthropic donations (Liket \& Maas, 2016). Firms voluntarily decide on which causes to invest monetarily in other to address certain social ills or misnomer in the society. The decision on which cause to support or advance may depend on the resultant reputational or economic effect (Liket \& Maas, 2016).

During the outbreak of the COVID-19 pandemic, some of the country's largest companies made highly visible commitment towards supporting the efforts of the government and health institutions. However, these commitments 
were made by organisations with already existing corporate reputation or financial performance. On a macro level, the response of corporate Nigeria in the form of various CSER initiatives has gone a long way in helping to manage the impact of the health pandemic (Covid-19). These CSER initiatives are aimed at strengthening the fight against the health pandemic in Nigeria.

Table 1. Nigerian listed companies and their contributions towards COVID-19

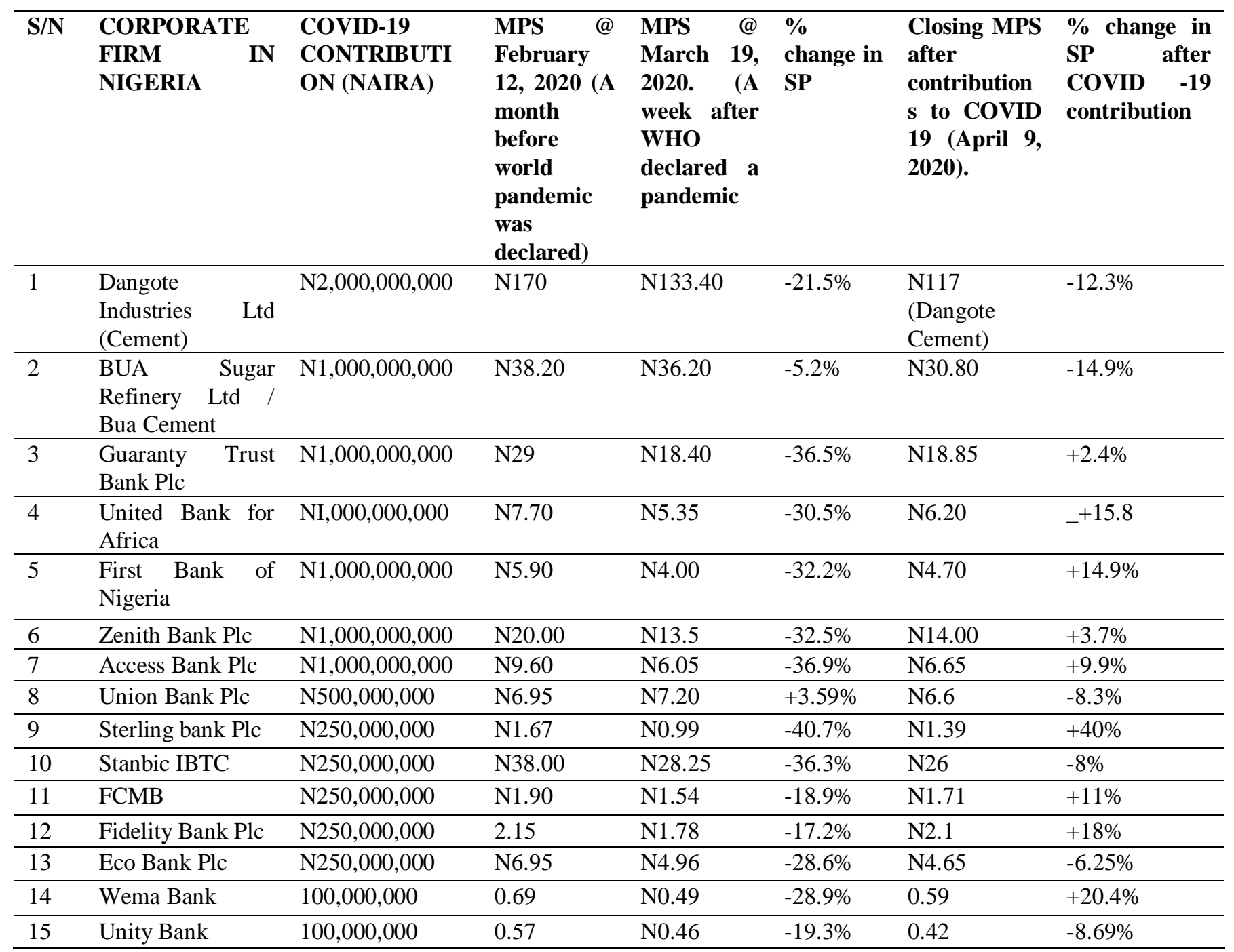

Adapted from CBN newsletter

Note: SP represents Share Price, MPS represents closing market price per share, \% Change in SP represents change in SP before the declaration of pandemic (By World Health Organisation) and after declaration of pandemic

Table 2. List of contributors not listed in the Nigeria Stock Exchange

\begin{tabular}{lll}
\hline S/N & CORPORATE FIRM IN NIGERIA & $\begin{array}{l}\text { COVID-19 } \\
\text { CONTRIBUTION } \\
\text { (NAIRA) }\end{array}$ \\
\hline 1 & Amperion Power Distribution Ltd & N1,000,000,000 \\
\hline 2 & Pacific Holding Ltd & N500,000,000 \\
\hline 3 & Standard Chartered Bank & $\mathrm{N} 250,000,000$ \\
\hline 4 & African Steel Mill Nigeria Ltd & $\mathrm{N} 250,000,000$ \\
\hline 5 & Multichoice Nigeria Ltd & $\mathrm{N} 200,000,000$ \\
\hline
\end{tabular}




\begin{tabular}{lll}
\hline 6 & FSDH Merchant Bank & $100,000,000$ \\
\hline 7 & FBN Merchant Bank & $100,000,000$ \\
\hline 8 & Rand Merchant Bank & $100,000,000$ \\
\hline 9 & Coronation Merchant Bank & $100,000,000$ \\
\hline 10 & Sun Trust Bank & $100,000,000$ \\
\hline 11 & Providus Bank & $100,000,000$ \\
\hline 12 & Heritage Bank & $100,00,000$ \\
\hline 13 & Nova Merchant Bank & $100,000,000$ \\
\hline 14 & Polaris Bank & $100,000.000$ \\
\hline 15 & Keystone Bank & $100,000,000$ \\
\hline 17 & Globus Bank & $100,000,000$ \\
\hline 18 & Titan Trust Bank & $50,000,000$ \\
\hline 19 & Takagro Chemicals Ltd & $50,000,000$ \\
\hline
\end{tabular}

Note: Adapted from CBN Newsletter

A review of the contributions made by various entities towards curbing the health pandemic revealed that the listed companies (whose shares are quoted in the Nigerian stock exchange) contributed more towards the pandemic than companies whose shares were not quoted. The average contribution from fifteen (15) listed companies was N663,300,000 while the average contribution from nineteen (19) unlisted companies was N179,210,526. Thus, the listed firms though fewer in number contributed more funds towards curbing the pandemic than the unlisted companies. A simple reason adduced is that listed firms have more access to capital or funds than unlisted firms. This simple analysis was in consensus with other studies that assume the relationship between CSER and FP is a virtuous circle (Orlitzky, Schmidt \& Rynes, 2003).

The world has gone through a series of health pandemics in the last century. The 1918 influenza, Spanish flu, Ebola crisis and recently the Covid-19 which has led to 177,000 deaths and infected over 2,400,000 people worldwide as at April 22, 2020. In all recorded history, only the black death that occurred throughout Europe from 1348 to 1351 is estimated to have killed more people (Garrett, 2008). These pandemics reveal that the corporate world should be prepared to make more investments towards the environment in the future. This is as a result of more efforts in recent times to come up with vaccines and antidotes to fight this virus. It has become imperative that corporate organisations need to make more provisions for contributions to the health and environment in other to ensure business sustainability. The recent pandemic in Nigeria may lead to a change in priority of societal needs and acceptance. Hence society is likely to reward organisations who make more investment towards mitigating the effects of the viral disease. This is in consensus with the legitimacy theory.

According to Ismail (2009), the classical view of CSER was restricted to philanthropy, then it moved to an emphasis on business society relations. Its major concern was the contribution of a corporate organisation to solving social problems. Corporate social environmental initiatives or philanthropic acts are discretionary in nature. Hence organisational managers can choose whether or not to comply with them (Hadoni \& Coombes, 2015; Zulfigar, 2016). The amount of donations made by firms vary significantly. There is no conclusive evidence defining how much organisations should donate to maximize economic benefits. However, the determining factor for the level of CSER is usually linked to size, profitability, visibility, political connections and resource availability (Zulfigar, 2016).

An avalanche of studies carried out have investigated the causal relationship between independent variables (Corporate Social Environmental Reporting) and dependent variable (Corporate Financial Performance). However, very few studies have attempted to examine the relationship between financial performance (Independent variable) and CSER (dependent variable). Theoretical and empirical studies reveal that organisational resources actually influence philanthropic activities. Hence studies that assume a uni-directional relationship between the two variables may not have attained efficient results. Thus the CSER-CFP relationship is significantly positive in both directions (Orlitzky, Schmidt \& Rynes, 2003; Palmer, 2012). It is against this backdrop that this study examines whether organisational slack affects the voluntary investment in CSER activities. The study also compares the share prices of listed companies in Nigeria before the announcement of the health pandemic, after the announcement of the health pandemic and after contributions in the form of COVID-19. 


\section{Literature Review}

Several billions of Naira have been spent by the Nigerian banks as their contribution towards addressing the social economic developmental challenges of the society. The contributions made by these banks have been in the areas of healthcare, education, security, agriculture, and charity donations (Odetayo, Adeyemi \& Sajuyigbe, 2014). The study revealed that donation to the health sector, the environment, community-based organisations and NGOS exceeded donations to other sectors. A vital issue in the relationship between social responsible actions and financial performance is that investments in pollution reduction, community donations and sponsorship to the community will erode the profitability of organizations and lead to competitive disadvantage (Alexander \& Buchholz, 1978). Thus, Organizational resource availability is a requirement in determining investment in CSER activities.

The work of Akpom and Gregg (2018) which examined the determinants of corporate social responsibility in developing countries revealed that the size of a company significantly affects CSER initiatives. Some other studies have linked CSER performance to board size and independence (Chang, Oh, Park and Jang, 2015; Hyung, Yang, Jung \& Hong, 2016). The relationship between firm size and CSER initiatives has also been examined in developing countries. The study which involved companies in Indonesia, utilized data obtained from Thomson Reuters. The findings revealed a U- shaped relationship between CSER and the size of the firm in developing countries. Therefore, low to medium sized visibility companies attained a higher CSER participation compared to medium to highly visible companies (Golrida, Mira \& Prem, 2019). Some other studies undertaken in Ghana find a negative relationship between Financial resource availability and CSER performance (Julian \& Ofori-Dankwa, 2013). A firms' financial situation and resource availability have a positive relationship with sustainable investment. Thus, establishing a link between revenue generation and environmental certification (Bowen, 2002, Segarra-Ona et al, 2012).

There has been a lack of consensus on the relationship between the resources availability of organizations and their CSER initiatives. Some studies found a positive relationship between the performance of an entity and its investment in CSER programs. (Gamerschlag et al, 2011, Shubiri et al, 2012, Gamrh \& Dhammari, 2016). While some other studies find a U shape relationship between smaller companies and CSER initiatives (Udayasankar, 2008). Resources and capabilities are used by firms to develop and implement their strategies. (Isabel, Jose \& Isaabel, 2011). According to Waddock and Graves (1997), the link between the CSP and CFP is simultaneous (that is operates in a virtuous circle). Thus, past FP of the firm affects CSP which then affects the future performance of the firm. This study thus extends the literature on the link between CSER and SP or FP. As organizational slack in the form of FP spurs CSER initiatives. Thus, confirming that doing well is doing good.

Empirical studies on the CSP and CFP link reveal that firms usually cut back on programs designed for CSER during economic downturn. (Singhal, 2014). However, companies are often required to provide assistance to challenges of human misery. With the astronomical increase in global population and the attendant child abuse, poverty and violent crime, there have been calls to corporate organizations to help out. The sheer magnitude of problems requires a collective effort involving public-private partnership (Margolis \& Walsh, 2003). Some other studies suggest that it may neither be prudent or possible to devote corporate resources to redress social misery (Friedman, 1970).

Legitimacy Theory: This asserts that the activities of an organization are appropriate and in tandem with the norms, beliefs and values held by the society (Suchman, 1995). Hence for organizations to continue to exist they must follow the values and norms of the society wherein it exist (Ali \& Isa, 2018). In addition, they must continue to engage in social and environmental initiatives that portray the beliefs and attitudes of the society (Vourvachis, Woodward, Woodward \& Patten, 2016). Several other studies have linked firm financial attributes such as firm size, leverage and profitability to activities of corporate social responsibility and its disclosure ( $\mathrm{Li} \&$ Zhang, 2010; Uwuigbe \& Egbide, 2012; Li et al, 2015; Mcguiness et al, 2016)

Resource-based or Slack Theory: In this study, CSR is the competitive advantage while financial slack resources are represented using monetary measure. Therefore, companies build economic competitive advantage because of access to resources (Mcwilliam \& Siegel, 2011). Slack resources are a buffer of potential or real resources which enable a firm to adapt to internal or external pressures. Therefore, slack resources work protect an entity in numerous ways from environmental uncertainty (Bourgeois, 1981). Some other studies are of the opinion that investment in CSER constitutes a misallocation of resources (Surroca \& Tribo, 2008). Investments in CSR can provide strategic benefits, providing opportunities for differentiation (Mcwilliams \& Siegel, 2000). Hence firms which accumulate slack resources will improve performance to the extent that the resources are invested in CSER (Mattingly \& Olsen, 2018). 


\section{Methodology}

An analysis of the listed companies and their closing market price per share (MPS) before the pandemic, during the pandemic and after contributions were made by corporate entities was conducted. COVID-19 was declared a world pandemic by the World Health Organisation (WHO) on March 11, 2020. The review of the MPS revealed that the percentage change in closing MPS between February 12, 2020 (a month before the world pandemic was declared) and March 19, 2020 (after the WHO declared a world pandemic) varied from $-5.2 \%$ to $-40.7 \%$. This excludes Union bank Plc which had $+3.59 \%$ increase in SP. Out of the 15 listed firms, 14 firms had significant drop in SP. This SP decline can be attributed to COVID - 19. Contributions were made by some listed and unlisted firms to fight the spread of the pandemic. These contributions were organised and collated by the Central Bank of Nigeria. According to the Central Bank Press release, these contributions occurred at the closing month of March and first week of April 2020. Consequently, the study revealed that some financial institutions (banks) experienced growth in SP after the COVID - 19 contribution. The SP growth was in the range of $+2.4 \%$ increase (GT Bank) to a $40 \%$ growth (Sterling bank). 9 companies out of 15 listed organisations experienced growth after the COVID -19 contributions.

\section{Results}

\subsection{Descriptive Analysis}

Table 3 presents the descriptive statistics for the corporate social and environmental disclosure score (EDISCI) alongside the share price variable as well as the firm specific variables (leverage and firm size) that serve as control variables

Table 3. Descriptive statistics

\begin{tabular}{lllll}
\hline Variables & Mean & Stddev & Min & Max \\
CSED & 0.51 & 0.19 & 0 & 1.00 \\
SP & 33.07 & 111.89 & 0.5 & 1555.99 \\
FSIZE & 7.06 & 0.79 & 5.09 & 9.22 \\
LEV & 0.59 & 0.25 & 0.00 & 2.24 \\
\hline
\end{tabular}

Note: $\mathrm{CSED}=$ corporate social and environmental disclosure; $\mathrm{SP}=$ Share Price; $\mathrm{LEV=leverage;} \mathrm{FSIZE=} \mathrm{firm} \mathrm{size}$

Table 3 highlights the description of the variables examined in the course of the study. The average for the extent of corporate social and environmental disclosure for the sampled firms was $0.51(51 \%)$

The mean for the share price is 33.07 , with a standard deviation of 111.8. The price of the shares ranges from the minimum of 0.5 to a maximum of 1555.99 . The standard deviation of 111.89 is a sign of volatility in the stock prices data. The description of the control variables are also shown in table 3. The mean for firm size (FSIZE) as measured using the log of total assets is 7.06, with a standard deviation of 0.79 . The assets amount range from the minimum of 5.09 to a maximum of 9.22. The mean total asset is comparable to Che-Ahmad and Osazuwa (2015) that reported a mean total assets of 7.65 . The average value for leverage is 0.59 , with a standard deviation of 0.25 , ranging from the minimum of 0.00 to a maximum of 2.24 .

\subsection{Correlation Results}

The correlation analysis of the variables is presented in Table 4 .

Table 4. Correlation analysis

\begin{tabular}{lllll}
\hline & CSED & SP & FSIZE & LEV \\
\hline CSED & 1.00 & & & \\
SP & 0.22 & 1.00 & & \\
FSIZE & 0.26 & 0.33 & 1.00 & \\
LEV & -0.06 & 0.07 & 0.11 & 1.00 \\
\hline
\end{tabular}

For variable definition see Table 3 
From the result of the correlation analysis in Table 4 above, we can see that there is absence of multicollinearity among the variables. This is also confirmed when we run the variance inflation factor (VIF) as it shows there is absence of multicollinearity among the variables with a mean VIF of 1.09 which is less than the maximum acceptable value of 10

Regression Results

In estimating the corporate social and environmental disclosure model we measure CSED using a disclosure index. Table 3 shows the result of the estimation. The Lagrangian Multiplier test rejects the null hypothesis of non-existence of effects in the cross-section units over time with p-values of 0.00. this implies that the pooled OLS estimator is not appropriate in the estimation of the CSED model. The result of the Hausman test with p-value of 0.32 reveal that the Random effect estimates are more appropriate than the fixed effect estimates. The models were then tested for heteroskedasticity and auto correlation. The result of the modified Wald test for heteroskedasticity with probability values $(\mathrm{P}<0.01)$ and Wooldridge test for autocorrelation with probability values $(\mathrm{P}<0.00)$ shows the presence of both problems in both models.

The panel models are then rectified of autocorrelation and heteroskedsaticity problems using the robust standard error estimates based on the stata command "xtreg cluster (code)" (Hoechle, 2007). The coefficient of multiple correlation of the random effects model is 0.0919 . The R-Square value shows that about $9.19 \%$ of the systematic cross-sectional variation of the dependent variable of CSED, is accounted for by the independent variables of share price, firm size and leverage. The Wald $\mathrm{Chi}^{2}$ of 66.68 obtained from the random effect model and the significant probability value of 0.0000 shows that a significant linear relationship exists between the dependent variable and the independent variables. Furthermore, the robust random effect regression results show that share price is significant and positively related corporate social and environmental disclosure $(\beta=0.0002, \mathrm{p}<.01)$. The result also shows firm size to be significant and positively related to CSED, while leverage was significant and negatively related

Table 5. Panel Regression Analysis

\begin{tabular}{llll}
\hline Variables & Pooled OLS & Fixed Effect & Random Effect \\
\hline SP & $0.0003(0.0001)^{* * *}$ & $0.0001(0.0001)$ & $0.0002(0.00004)^{* * *}$ \\
\hline FSIZE & $0.0495(0.0096)^{* * *}$ & $0.1282(0.0436)^{* * *}$ & $0.0615(0.0203)^{* * *}$ \\
\hline LEV & $-0.0804(0.0286)^{* * *}$ & $-0.0644(0.0360)^{*}$ & $-.0723(0.0331)^{* *}$ \\
\hline CONS & $0.2023(0.0682)$ & $-0.3574(0.3095)$ & $0.1140(0.1437)$ \\
\hline $\mathrm{R}^{2}$ & 0.0946 & 0.0754 & 0.0919 \\
\hline LM Test & & 204.75 & \\
& & $(0.00)$ & \\
\hline Hausman Test $(\chi 2)$ & 3.54 & \\
& & $(0.32)$ & \\
\hline F-stat & 22.49 & 4.75 & 66.68 \\
& $(0.00)$ & $(0.0028)$ & $(0.00)$ \\
\hline Wald $\mathrm{Chi}^{2}$ & & & \\
& & & \\
\hline
\end{tabular}

Note: coefficient values are stated with standard errors in parenthesis; *sig 10\%, **5\%, ***1\%

\section{Conclusions}

The plethora of existing studies on the relationship between CSER and firm share prices have assumed a uni-directional relationship. These studies have assumed financial performance (FP) as a dependent variable in the CSER and FP link. Thus, this analysis may not have attained efficient results as they do not consider endogeneity bias arising from the impact of firm performance or sustainability initiatives. This study therefore concurs to the slack resources theory of Waddock and Graves and the virtuous circle. Therefore, CSER initiatives may lead to better FP performance while SP performance will lead to more involvement in CSER activities. The findings of the study reveal that companies with lower level of financial capabilities will have challenges responding to changes in stakeholder expectations. The financial slack becomes even more important as a result of the thinning of resources occasioned by economic downturns and health pandemics.

The Corona virus (COVID-19) has led to an unprecedented disruption in global supply chains, sharp drop in global crude oil prices, and lock down which have disrupted economic activities and reduced revenue generated by listed 
and unlisted firms. The pandemic has also proven that the world is indeed a global village. Thus a health pandemic in one nation can easily affect another country. This has implications for multinational companies. However, this study recognizes the collective impact of organizations in the fight against the epidemic. It also recommends a private Government partnership. Finally, the study recommends that the corporate world should be prepared for a change in stakeholder expectation and societal demands given the recent pandemic. Only corporate organisations with adequate financial resources can make significant contributions in the form of CSER initiatives.

The experiences around the world in the last few months reveal that nations (Nigeria inclusive) are not prepared for a viral pandemic. The occurrences also reveal the weakness if the health sector and reappraises the jobs that are critical or termed essential. Therefore smaller firms that are unable to invest significantly in health and Information Technology may be punished by the society.

\section{References}

Akpom, U., \& Gregg, J. (2018). The Impact of Company Size on Corporate Social Responsibility: Empirical Evidence from a Developing Economy. Journal of Business and Economic Policy, 5(1), 31-36.

Ali, S. M., \& Isa, M. A. (2018). Firms Attributes and Corporate Social Responsibility Disclosure; A literature Review. International Journal of Academic Research in Business and Social Sciences, 8(4), 312-325. https://doi.org/10.6007/IJARBSS/v8-i4/4016

Bourgeois, L. J. (1981). On the measurement of organizational slack. Academy of Management Review, 6(1), 29-39. https://doi.org/10.5465/amr.1981.4287985

Bowen, F. E. (2002). Does Size Matters? Organizational Slack and Visibility as Alternative explanations for environmental responsiveness. Business and Society, 41, 18-24. https://doi.org/10.1177/0007650302041001007

Chang, Y. K., Oh, W. Y., Park, Y. H., \& Jang, M. G. (2015). Exploring the relationship between board characteristics and CSR: Empirical evidence from Korea. Journal Business Ethics, 140(2), 225-242. https://doi.org/10.1007/s10551-015-2651-z

Friedman, M. (1970, September). The social responsibility of business is to increase its profits. New York Times Magazine, 32(33), 122-126.

Gamerschlag, R., Moller, K., \& Verbeeten, F. (2011). Determinants of Voluntary CSR Disclosure: Empirical evidence from Germany. Rev Mang Sci, 5(2), 233-262. https://doi.org/10.1007/s11846-010-0052-3

Gamrh, B. A., \& Redhwan, A. (2016). Firm Characteristics and Corporate Social Responsibility. International Business Management, 10(18), 4283-4291.

Golrida, K. P., Mira, M., \& Prem, L, J. (2019). Re-examining Firm Size and Corporate Social Responsibility; The Visibility Approach. Emerging Market Journal, 9(1), 1-15. https://doi.org/10.5195/emaj.2019.160

Hyun, E., Yang, D., Jung, H., \& Hong, K. (2016). Women on boards and corporate social responsibility. Sustainability, 8, 1-26. https://doi.org/10.3390/su8040300

Isabel, G., Jose, M., \& Isabel-Maria, G. (2011). Corporate Social Responsibility and Innovation: a resource-based theory. Management Decision, 49(10), 1709-1727. https://doi.org/10.1108/00251741111183843

Julian, S. D., \& Ofori-dankwa, J. C. (2013). Financial Resource Availability and Corporate Social Responsibility Expenditure in a Sub- Saharan economy. The Institutional difference hypothesis. Strategic Management Journal, 34(11), 1314-1330. https://doi.org/10.1002/smj.2070

Li, S., Song, X., \& Wu, H. (2015). Political Connection, Ownership Structure, and Corporate Philanthropy in China: A Strategic Political Perspective. Journal of Business Ethics, 129(2), 399-411. https://doi.org/10.1007/s10551-014-2167-y

Li, W., \& Zhang, R. (2010). Corporate Social Responsibility, ownership structure, and political interference; Evidence from China. Journal of Business Ethics, 96(4), 631-645. https://doi.org/10.1007/s10551-010-0488-Z

Margolis, J., \& Walsh, J. (2003). Misery Loves Companies; Rethinking Social Initiatives by Business. Administrative Science Quarterly, 48(268), 268-305. https://doi.org/10.2307/3556659

Mattingly, J. E., \& Olsen, L. (2018). Performance Outcomes of Investing Slack Resources in Corporate Social Responsibility. Journal of Leadership \& Organizational Studies, 1-45. https://doi.org/10.1177/1548051818762336 
Mcguinness, P. B., Vieito, J., \& Wang, M. (2016). CSR Performance in China: The Role of Board Gender and Foreign Ownership. Journal of Corporate Finance. https://doi.org/10.1016/j.jcorpfin.2016.11.001

McWilliams, A., \& Siegel, D. (2000). Corporate Social Responsibility: A theory of the firm perspective. Academy of Management Review, 26(1), 117-127. https://doi.org/10.5465/amr.2001.4011987

Odetayo, T. A., Adeyemi, A. Z., \& Sajuyigbe, A. S. (2014). Impact of Corporate Social Responsibility on Profitability of Nigerian Banks. International Journal of Academic Research in Business and Social Sciences, 4(8), 252-263. https://doi.org/10.6007/IJARBSS/v4-i8/1094

Segarra-Ona, M., Angel, P., Rohit, V., \& Luis, M. (2012). Does Environmental Certification help the Economic Performance of Hotels? Evidence from the Spanish Hotel Industry. Cornell Hospitality Quarterly, 53, 242-56. https://doi.org/10.1177/1938965512446417

Shubiri, F. N., Al-abedallat, A. Z., \& Orabi, M. (2012). Financial and non-financial determinants of Corporate Social Responsibility. Journal of Knowledge Management, Economics Information Technology, 5(2).

Singal, M. (2014). The Link between Firm Financial Performance and Investment in Sustainability Initiatives. Sustainability \& Finance. Cornell Hospitality Quarterly, 53(1), 19-30. https://doi.org/10.1177/1938965513505700

Suchman, M. C. (1995). Managing Legitimacy: Strategic and Institutional Approaches. Academy of Management Review, 20, 571-610. https://doi.org/10.5465/amr.1995.9508080331

Surroca, J., \& Tribo, J. A. (2008). Managerial Entrenchment and corporate social performance. Journal of Business Finance \& Accounting, 35, 748-789. https://doi.org/10.1111/j.1468-5957.2008.02090.x

Udayasankar, K. (2008). Corporate Social Responsibility and Firm Size. Journal of Buisness Ethics, 83(2), 167-165. https://doi.org/10.1007/s10551-007-9609-8

Uwuigbe, U., \& Egbide, B. C. (2012). Corporate Social Responsibility Disclosure in Nigeria: A Study of Listed Financial and Non-financial firms. Journal of Management and Sustainability, 2(1), 160-169. https://doi.org/10.5539/jms.v2m1p160

Vourvachis, P., Woodward, T., Woodward, D. G., \& Patten, D. M. (2016). CSR disclosure in response to major airline accidents: a legitimacy-based exploration. Sustainability Accounting, Management and Policy Journal, 7(1), 26-43. https://doi.org/10.1108/SAMPJ-12-2014-0080

Waddock, A. S., \& Graves, S. B. (1997). The Corporate Social Performance, Financial Performance Link. Strategic Management Journal, 303-319. https://doi.org/10.1002/(SICI)1097-0266(199704)18:4<303::AID-SMJ869>3.0.CO;2-G

\section{Copyrights}

Copyright for this article is retained by the author(s), with first publication rights granted to the journal.

This is an open-access article distributed under the terms and conditions of the Creative Commons Attribution license (http://creativecommons.org/licenses/by/4.0/). 